\title{
The Effect of Organizational Commitment and Internal Communication on Job Satisfaction and Performance of Informal Education Institution Employee
}

\author{
Endang Saefuddin Mubarok ${ }^{1}$ Wiwin $^{1} \quad$ Syahrullah $^{2} \quad$ Rudi Salam $^{3}$ \\ 1.Faculty of Economics, Jakarta Islamic University, Jakarta, Indonesia \\ 2.Faculty of Islamic Studies, Jakarta Islamic University, Jakarta, Indonesia \\ 3.Sekolah Tinggi Ilmu Statistik, Statistics Higher Education Institute, Indonesia
}

\begin{abstract}
Employee performance at informal educational institutions has an important role in supporting the achievement of organizational goals. However, the identification of the determining factors and their impact on employee performance at the institution is often done partially. This study focuses on three factors, namely organizational commitment factors, internal communication, and job satisfaction. Specifically, the aim of this study was to examine the effect of organizational commitment and internal communication on job satisfaction and employee performance at informal educational institutions in Kampung Inggris, Pare Indonesia. In this study, organizational commitment and internal communication act as independent variables, employee performance acts as the dependent variable, and job satisfaction acts as a mediator variable. This study uses a questionnaire to collect data. The sample obtained and valid for use was 116 . Structural equation modeling was used to analyze the data. The results of the analysis indicate that organizational commitment and internal communication factors have a positive and significant effect on job satisfaction and employee performance in informal educational institutions in Kampung Inggris, Pare region, Indonesia. This finding implies that these institutions need to find and implement ways to build a system of internal communication and organizational commitment and direct it to increase job satisfaction in order to improve the performance of their employees.
\end{abstract}

Keywords: organizational commitment, internal communication, job satisfaction, employee performance

DOI: $10.7176 / \mathrm{EJBM} / 13-3-09$

Publication date: January $31^{\text {st }} 2021$

\section{Introduction}

In the current era of globalization, learning English has an important role for young people in Indonesia, especially for their educational goals and their future. English is one of the international languages used in many countries, even in some countries, English is a second language for the people. As an international language of communication, English has importance for various development sectors in Indonesia. One of the sectors where English plays an important role is the tourism sector. Indonesia is a country that has cultural diversity and is one of the destinations for foreign tourists. It is very important for young people to learn English, it is very important, especially in terms of their education. The younger generation can introduce this diversity of Indonesian culture and language to those who want to learn more about the Indonesian nation. In addition, by mastering English, the generation will have a great opportunity to get a job, be ready for tourism, and continue their education to a higher level (Crystal, 2003).

Kampung Inggris (English Village) is the nickname for the villages of Tulungrejo and Palem which are located in Pare District, East Java Province, Indonesia. Kampung Inggris is an area where many people can take part in teaching and learning activities that are specialized in learning English. People who study in Kampung Inggris come from many regions in Indonesia, even people from abroad. Initially, around 1977, there was only one English language course institute, namely the Basic English Course (BEC). This informal educational institution teaches not only English but also religious knowledge. In 2019, there are more than 100 informal educational institutions in the village with more than 5,000 students. The number of students who come to Kampung Inggris to improve their skills in speaking English continues to increase. These students come from various parts of Indonesia as well as students from abroad. The achievements of Kampung Inggris in developing English language skills and religious knowledge of students reflect the performance of employees of educational institutions in the village in carrying out their duties as English teachers.

Employee performance has a very important role to support the success of an educational institution. High employee performance will result in high organizational performance while low employee performance will cause low organizational performance (Amstrong \& Baron, 2009; Bernarddin and Russel, 2003). Employee performance, among others, can be seen from the aspects of quantity, quality, working time, and cooperation in achieving the organizational goals that have been set. Literature studies show that employee performance is influenced by many factors, both external and internal factors (Cushway, 2002). This study focuses on three factors, namely organizational commitment factors, internal communication, and job satisfaction. Specifically, the aim of this 
study was to examine the effect of organizational commitment and internal communication on job satisfaction and employee performance at informal educational institutions in Kampung Inggris Indonesia. In this study, organizational commitment and internal communication act as independent variables, employee performance acts as the dependent variable, and job satisfaction acts as a mediator variable.

\section{Literature review and hypothesis development}

\subsection{Organizational Commitment}

Organizational commitment can be understood in different ways. For example, organizational commitment can be defined as the strong desire of employees to remain members of a particular organization, the desire of employees to work actively in accordance with the wishes of the organization, and the beliefs of employees in the values and goals of the organization (Gibson et al., 2008). . In other words, organizational commitment is an attitude that reflects employee loyalty to the organization where employees direct their attention to organizational goals and success. In addition, organizational commitment can be understood as a condition in which an employee [1] takes sides and believes in the organization where he works, [2] is willing to accept organizational goals, [3] and his desire to maintain membership in the organization. Organizational commitment also refers to the desire of employees to remain as members of a particular organization, the desire to try hard in accordance with the wishes of the organization, and the acceptance of employees for organizational values and goals (Reggio et al., 2008).

Furthermore, the literature recognizes that organizational commitment is a multidimensional construct. In this case, it is generally recognized that organizational commitment includes three dimensions, namely affective commitment, sustainability commitment, and normative commitment (Luthans, 2008). Affective commitment is an emotional attachment, identification, and involvement of employees in the organization. Sustainability commitment refers to employees' awareness of the harm that would be incurred if they left the organization. Normative commitment is a feeling that arises in employees to stay in the organization because it is the right thing to do (Davis and Newtorn, 2006).

\subsection{Internal communication}

Internal communication can be understood as communication that occurs in an organizational environment. This communication can occur between employees and employees, employees and superiors, and superiors and superiors. Internal communication can also be referred to as the exchange of ideas among employees in an organization, both horizontal exchange of ideas and vertical exchange of ideas within an organization. In addition, internal communication can be defined as the delivery of information from an employee to another employee (D'Aprix, 1982). Internal communication will work well if mutual understanding arises between the sender and recipient of the message, so that what is communicated can be understood and implemented. Without good internal communication, work will become chaotic so that organizational goals are unlikely to be achieved effectively. Internal communication allows an employee to receive information in accordance with what is in the mind of the messenger (Pace and Faules, 2000; Subari, 2014). Literature shows that internal communication has an important role in supporting employee performance improvement.

According to Kalla (2006), internal communication can be divided into two, namely vertical communication and horizontal communication. Vertical communication can be classified into two, namely communication from the leader to the employee and communication from the employee to the leader. In vertical communication, several processes take place, such as giving instructions, directions, and information from leaders to employees. In addition, vertical communication also takes place several processes such as providing reports, suggestions, and complaints from employees to leaders (Bovee and Thill, 2000). Meanwhile, horizontal communication refers to the communication that occurs between one employee and one employee or manager and another manager. In contrast to vertical communication which is more formal, horizontal communication often takes place informally. Horizontal communication usually takes place when they are taking a break or when they come home from work. In particular, the literature suggests that horizontal communication within an organization has four functions, namely coordination between department heads, solving problems that arise within one department, sharing information between individual members of one department, and resolving conflicts within departments or between departments (Rogusa, 2010; While Riel, 1997).

\subsection{Job Satisfaction}

Job satisfaction can be understood as a pleasant feeling which is the result of individual perceptions in order to complete a task or fulfill his need to obtain work values that are important to him; the level of positive and pleasant emotions of the individual which is the result of the individual's estimation of work or positive and pleasurable experiences; or the way employees feel themselves or their jobs (Hasibuan, 2007; Colquitt et al., 2012). Dessler (2013) suggests that job satisfaction is a general attitude of an individual towards his job. As is well known, daily work requires individuals to interact with colleagues and superiors, follow organizational rules and policies, and meet performance standards. Luthan and Farlin, 2008) suggest that the job satisfaction of an employee, or an 
employee's assessment of his job, is the sum of the elements of the job.

Apart from that, job satisfaction also refers to the pleasant attitude that employees develop over time regarding various aspects of their work. This attitude comes from employees' perceptions of aspects of their work such as wages, promotion opportunities, and coworkers (Robbinson and Judge, 2011). A similar opinion was expressed by Wexley and Yulki (2010) who stated that job satisfaction is an emotional state of employees as a reflection of the employee's own attitude, work situation, cooperation between leaders and employees. It is an individual's perception of work which is the result of a subjective assessment of aspects of the job which includes satisfaction with the job itself, salary received, opportunities for promotion and career development, quality of supervisors and relationships with colleagues, career development opportunities, relationships with employees others, work placement and organizational structure.

\subsection{Employee Performance}

Employee performance can be understood in different ways. For example, employee performance can be understood as the quality and quantity of work performed by an employee in carrying out his duties in accordance with the responsibilities assigned to him, a set of results achieved from the implementation of a job performed by the employee, or the quality and validation of tasks. whether done by individuals or groups of employees (Armstrong \& Baron, 2009; Bernarddin and Russel, 2003). In addition, employee performance also refers to the level of success of employees in carrying out their duties and the ability of employees to achieve predetermined goals (Subari, 2014; Cushway, 2002). Employee performance will be declared high if the goals that have been set can be achieved properly. The literature also suggests that performance is a function of three variables, namely ability, motivation, and opportunity. In addition, performance is also seen as the result of work achieved by a person in carrying out his duties on skills, effort and opportunity. Thus, employee performance is a result achieved by a person in carrying out tasks according to predetermined standards and criteria (Mathis and Jackson, 2004).

Given the importance of employee performance in supporting the achievement of organizational goals, an educational institution needs to implement performance management in their operations. According to Rucky (2009), performance management is a strategic and integrated approach to achieve organizational success in a sustainable manner by improving the performance of employees who work in it. Performance management also aims to develop the capabilities of employees and groups and their contribution to support organizational goals. The literature also suggests that performance management is a management tool that enables managers to monitor and evaluate employee work. The goal of performance management is to create an environment where people can do the best of their ability to produce the highest quality work efficiently and effectively. The implementation of performance management can assist managers and employees in evaluating directly the goals and progress of the organization, including the alignment of individual work with the company's overall vision (Robbins, 2003).

\subsection{Conceptual Framework}

The purpose of this study was to examine the effect of organizational commitment and internal communication on job satisfaction and employee performance at informal educational institutions in Kampung Inggris Indonesia. In this study, organizational commitment and internal communication act as independent variables, employee performance acts as the dependent variable, and job satisfaction acts as a mediator variable. Based on the literature review, this study proposes a conceptual framework as shown in Figure 1.

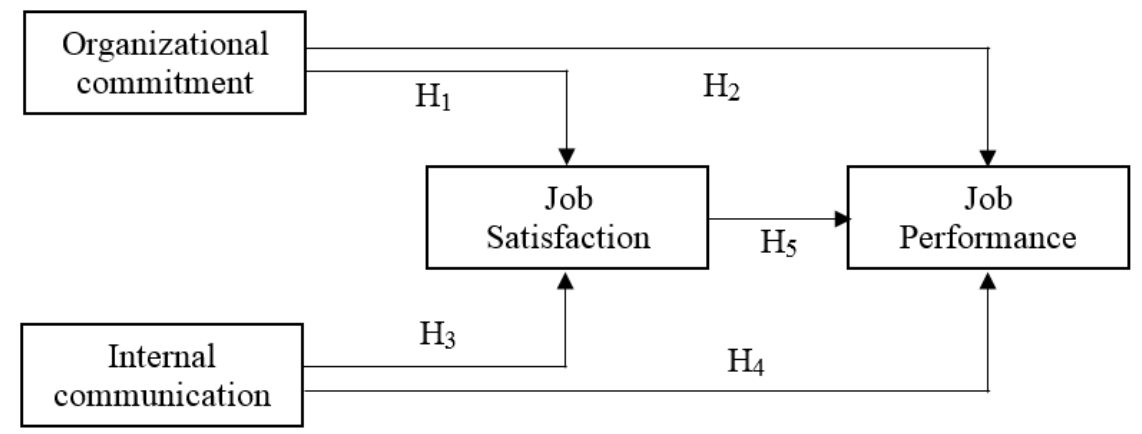

Figure 1

Conceptual framework of this study

The framework presumes that informal educational institutions need to improve the performance of their employees in order for these institutions to develop and be successful. To achieve this goal, these institutions need to build an organizational environment that allows for the emergence of organizational commitment among their employees and seek ways to develop internal communication within the organization, both vertical and horizontal. This organizational commitment and internal communication is further directed at increasing job satisfaction and employee performance. The conceptual framework of this study consists of four constructs, namely organizational 
commitment, internal communication, job satisfaction, and employee performance. This study views that previous research has more frequently examined the effect of organizational commitment, internal communication, and job satisfaction on employee performance separately. Therefore, this study considers the need for further research to examine the relationship between the four constructs simultaneously. In this regard, this study proposes five hypotheses which will be examined in the context of informal educational institutions in Kampung Inggris, Pare, Indonesia. Table 1 presents the five hypotheses proposed in this study.

Table 1

Hypotheses proposed in this study

\begin{tabular}{cl}
\hline Hypotheses & \multicolumn{1}{c}{ Description } \\
\hline 1. & $\begin{array}{l}\text { Organizational commitment is positively associated with employees job satisfaction of } \\
\text { informal educational institutions in Kampung Inggris }\end{array}$ \\
2. & $\begin{array}{l}\text { Organizational commitment is positively associated with employees performance of } \\
\text { informal educational institutions in Kampung Inggris }\end{array}$ \\
3. & $\begin{array}{l}\text { Internal communication is positively associated with employees job satisfaction of } \\
\text { informal educational institutions in Kampung Inggris }\end{array}$ \\
4. & $\begin{array}{l}\text { Internal communication is positively associated with employees performance of informal } \\
\text { educational institutions in Kampung Inggris }\end{array}$ \\
5. & $\begin{array}{l}\text { Job satisfaction is positively associated with employees performance of informal } \\
\text { educational institutions in Kampung Inggris }\end{array}$
\end{tabular}

\section{Research Methodology}

\subsection{Research design}

The purpose of this study was to examine the effect of organizational commitment and internal communication on job satisfaction and employee performance at informal educational institutions in Kampung Inggris Indonesia. In this study, organizational commitment and internal communication act as independent variables, employee performance acts as the dependent variable, and job satisfaction acts as a mediator variable. This study uses a questionnaire to collect data. Data collection took place from September to December 2019. The questionnaire was distributed to 300 employees who work at informal educational institutions located in Kampung Inggris, East Java Province, Indonesia. In the end, the number of questionnaires obtained and valid to use was 116. Structural equation modeling was used to analyze the data.

\subsection{Variable measurement}

Organizational commitment

Following Allen and Meyer (1990), this study views that organizational commitment is a multidimensional construct, namely affective commitment, ongoing commitment, and normative commitment. Employees who have a strong affective commitment will continue to work in an organization because they really want to work for that organization. Employees who have a strong ongoing commitment will stay with an organization because they need it. Employees who have a strong normative commitment will cause them to stay in the organization because they have the view that working for the organization is something that is right.

Internal communication

Referring to Fletcher (1999), this study uses eight items to measure internal communication variables. This study views that internal communication as an exchange of ideas between employees and employees, employees with leaders, and leaders and leaders which causes the organizational and management processes at informal educational institutions in Kampung Inggris.

Job satisfaction

Referring to Oshagbemi (1997), this study views that job satisfaction is the attitude and feelings of employees which are a reflection of their perceptions of various aspects of work such as employee opportunities to develop careers in organizations, employee security in doing daily work, salaries and wages that are accepted by employees, management skills in managing institutions, employee supervision systems, work suitability with employees' abilities and expectations, work environment and facilities, communication between individuals, and the social impact of work.

Employee performance

Referring to the literature (Kreitner, 2009; Storey, 2004), this study uses ten indicators to measure employee performance variables. These indicators include the conformity of work results with the standards set by the organization, employee involvement in the completion of individual and group work, conformity of work results with established quality standards, suitability of the amount of work that can be completed with predetermined targets, the duration required for completing work, employee efforts in improving work results, employee 
discipline in using time and completing work, and employee ability to complete work in accordance with leadership instructions.

\section{Results and Discussion}

\subsection{Overview of respondents}

Based on data from the respondents, this study found that the majority of employees at educational institutions in Kampung Inggris (46 percent) are between the ages of 30-39. In other words, the age of the majority of employees in these institutions is in the productive age category. The study also found that the majority of employees at these institutions (67 percent) had a bachelor's degree. This finding indicates that the majority of employees at these institutions are individuals with educational backgrounds sufficiently qualified to become teachers of English. Furthermore, this study found that the majority of employees at educational institutions in Kampung Inggris (41 percent) have a work period of 5 - 10 years. Thus, it can be said that the majority of employees at these institutions already have sufficient experience as English teachers.

\subsection{Validity and reliability test}

This study tested the validity and reliability of the construct by using confirmatory factor analysis through convergent validity and discriminant validity. This test is intended to show how the manifest / observer variable variables represent the construct being measured. In this study, an item will be declared valid if the item has a loading factor greater than 0.70. For the purpose of this study, Average Variance Extracted (AVE) was used to test the reliability of the construct. The minimum AVE value required in this study is 0.60 . The results of the analysis show that the minimum factor loading is 0.71 and the maximum factor loading is 0.90 . Furthermore, the analysis results show that the minimum AVE is 0.61 and the maximum AVE is 0.76 .

\subsection{Descriptive analysis}

This study aims to investigate the effect of organizational commitment and internal communication on job satisfaction and employee performance at informal educational institutions in Kampung Inggris, Pare, Indonesia. The first independent variable studied was organizational commitment. In this study, the items used to measure organizational commitment variables were adopted from the work of Allen and Meyer (1990). The results of the analysis show that the employees' expectation to benefit from the organization if they remain as employees is the organizational commitment item that has the lowest score (3.2 points) while the employee's desire to continue to be part of the organization for a long time is an organizational commitment item that has the lowest score (3.2 points). highest score (4.4 points). The second independent variable studied is internal communication. In this study, the items used to measure internal communication variables were adopted from the work of Fletcher (1999). The results of the analysis show that the employees' expectation to benefit from the organization if they remain as employees is the internal communication item which has the lowest score (3.1 points) while the attention of the organization's leadership towards all employees is the internal communication item which has the highest score (4.6 points).

The third variable examined in this study is job satisfaction. For the purposes of this study, job satisfaction acts as the first dependent variable. The items used to measure this variable were adopted from the work of Oshagbemi (1997). The results of the analysis show that employee satisfaction with the physical environment in which they work is the employee performance item that has the lowest score (3.2 points) while the employee's satisfaction in teaching English is the employee performance item that has the highest score (4.4 points). For employee performance variables, the items used in this study were adopted from the work of Storey (2004). The results of the analysis show that employee compliance in wearing work uniforms in their daily work at work is the employee performance item that has the lowest score (3.5 points), while the employee is able to complete the tasks assigned according to standard procedures that have been set is the employee performance item that has a score. highest (4.6 points).

\subsection{Structural model}

The purpose of this study was to examine the effect of organizational commitment and internal communication on job satisfaction and employee performance at informal educational institutions in Kampung Inggris Indonesia. In this study, organizational commitment and internal communication act as independent variables, employee performance acts as the dependent variable, and job satisfaction acts as a mediator variable. For this reason, this study has developed a structural model that represents the simultaneous relationship between organizational commitment, internal communication, job satisfaction, and employee performance (Figure 1). Table 2 shows the results of testing the structural model for the relationship of the four constructs (Probability level $=0.05$; GFI $=$ $0.966 ;$ TLI $=0.958 ;$ RMSEA $=0.051$ ) 
Table 2 Structural model test results

\begin{tabular}{|l|l|l|}
\hline \multicolumn{1}{|c|}{ Relationship } & SRW & CR \\
\hline Organizational commitment and job satisfaction & $0.344^{\circ *}$ & 0.483 \\
Organizational commitment and employees performance & $0.623^{\circ * *}$ & 0.766 \\
Internal communication and job satisfaction & $0.311^{\circ *}$ & 0.461 \\
Internal communication and employees performance & $0.219^{\circ *}$ & 0.420 \\
Job satisfaction and employees performance & $0.536^{\circ * *}$ & 0.621 \\
\hline
\end{tabular}

$* *$ : significant at $\alpha=0.05 * * *$ : significant at $\alpha=0.01$

\subsection{Analysis}

The first objective of this study was to examine the relationship between organizational commitment and employee job satisfaction at informal educational institutions in Kampung Inggris, Pare, Indonesia. This study proposes a hypothesis that organizational commitment and job satisfaction are positively correlated. In other words, the higher the organizational commitment, the higher the employee's job satisfaction. The results of the analysis show that organizational commitment has a positive effect on employee job satisfaction $(\beta=0.344 ; p<0.05)$ so that the first hypothesis is accepted. The next objective of this study was to examine the relationship between organizational commitment and employee performance at informal educational institutions in Kampung Inggris, Pare, Indonesia. This study proposes a hypothesis that organizational commitment and employee performance are positively correlated. In other words, the higher the organizational commitment, the higher the employee's performance. The results of the analysis show that organizational commitment has a positive effect on employee performance ( $\beta=$ $0.623 ; \mathrm{p}<0.01$ ) so that the second hypothesis is accepted.

The third objective of this study was to examine the relationship between internal communication and employee job satisfaction at informal educational institutions in Kampung Inggris, Pare, Indonesia. This study proposes a hypothesis that internal communication and job satisfaction are positively correlated. In other words, the higher the organizational commitment, the higher the employee's job satisfaction. The results of the analysis show that internal communication has a positive effect on employee job satisfaction $(\beta=0.311 ; p<0.05)$ so that the third hypothesis is accepted. The next objective of this study is to examine the relationship between internal communication and employee performance at informal educational institutions in Kampung Inggris, Pare, Indonesia. This study proposes a hypothesis that internal communication and employee performance are positively correlated. In other words, the higher the internal communication, the higher the employee's performance. The results of the analysis show that internal communication has a positive effect on employee performance ( $\beta=0.219$; $\mathrm{p}<0.05$ ) so that the fourth hypothesis is accepted. The final objective of this study was to examine the relationship between job satisfaction and employee performance at informal educational institutions in Kampung Inggris, Pare, Indonesia. This study proposes a hypothesis that job satisfaction and employee performance are positively correlated. In other words, the higher the job satisfaction, the higher the employee's performance. The results of the analysis show that job satisfaction has a positive effect on employee performance $(\beta=0.536 ; p<0.01)$ so that the fifth hypothesis is accepted.

This study found that organizational commitment has a significant effect on job satisfaction and employee performance. These findings imply that informal educational institutions in Kampung Inggris need to build an organizational environment that allows for increased organizational commitment from their employees. This organizational commitment refers to a situation where employees take the side of the organization where they work, support organizational goals, and intend to maintain their membership in the organization where they work. In other words, the organizational environment of informal educational institutions in Kampung Inggris needs to be directed towards building trust from employees in the organization, supporting the achievement of organizational goals, accepting organizational values, the desire to maintain relationships between employees and the organization, and willingness to make great efforts for the success of the organizations they work for.

Informal educational institutions in Kampung Inggris generally have several departments that have different goals and involve many employees. With so many employees involved, there needs to be internal communication to align their vision and ways of achieving departmental and organizational goals simultaneously. For this reason, organizations need to build effective internal communication tools and use them as a means of mutual communication, eliminate misunderstandings or barriers to communication between leaders and employees, and to explain organizational policies and regulations. In addition, internal communication can also be used as a means for employees to convey suggestions, wishes, and reports to the leadership of the organization. It should be emphasized that the internal communication system built allows two-way communication. By using this system, 
both leaders and employees can communicate according to their wishes, for example asking relevant questions and discussing someone's intentions openly and honestly. Internal communication which takes place in two directions has an important role for informal educational institutions in Kampung Inggris in making decisions regarding ways to achieve the goals of the institution that have been set.

\section{Conclusion}

The results showed that organizational commitment had a positive influence on employee job satisfaction at informal educational institutions in Kampung Inggris. In other words, the higher the organizational commitment, the employee job satisfaction will also increase. These findings indicate that organizational commitment is one of the important factors that can affect employee job satisfaction. The literature suggests that employee commitment to the organization can increase job satisfaction for employees and support the achievement of organizational goals in general (Gibson et al., 2008). Organizational leaders can build employee empowerment programs in order to strengthen organizational commitment through analysis of position, trust, credibility and employee accountability. The results of this study emphasize the importance of organizational employee commitment to increasing employee job satisfaction at informal educational institutions in Kampung Inggris. In addition, this study found that organizational employee commitment has a positive effect on employee performance at informal educational institutions in Kampung Inggris. In other words, employee commitment to the organization can play a role as a driving factor for improving employee performance at these institutions. The stronger the organizational commitment, the higher the employee's performance. These findings support the idea that organizational commitment is one of the important factors that can affect employee performance.

Furthermore, this study found that internal communication has a significant positive effect on employee job satisfaction at informal educational institutions in Kampung Inggris. This means that the better and more effective internal communication in these institutions, the employee job satisfaction will increase. These findings support the idea that internal communication is one of the important factors that can affect employee job satisfaction. Thus, institutional leaders need to build an effective communication system so that a message can be received and understood by message recipients. This effective internal communication can lead to increased employee motivation so that they are willing to devote all their abilities to achieve organizational goals (Argenti and Forman, 2002). In addition, this study found that internal organizational communication has a positive influence on employee performance at informal educational institutions in Kampung Inggris. In other words, internal communication can play a role as a driving factor for improving employee performance at these institutions. The more effective internal communication is, the higher the employee's performance. These findings support the idea that internal communication is one of the important factors that can affect employee performance. Finally, this study found that job satisfaction has a positive influence on employee performance at informal educational institutions in Kampung Inggris. In other words, job satisfaction can act as a driving factor for improving employee performance at these institutions. The higher the job satisfaction, the higher the employee's performance. These findings support the idea that job satisfaction is one of the important factors that can affect employee performance.

\section{References}

Armstrong, Mickael \& Angela Baron. 2009. Performance Management. London: Institute of Personal and Development.

Argenti, P. A., \& J. Forman. 2002. The Power of Corporate Communication: Crafting The Voice and Image of Your Business. New York: McGraw-Hill.

Bagozzi, Rezard P. \& Youyae Yi. 1989. On The Use of Structural Equation Models in Experience Designs. Journal of Marketing Research, Augt.

Bavee, Coutland \& John V. Thill. 2000. Business Communication Today. Fifth Edition. New Jersey: Prentice Hall.

Bernardin, H. John \& Joyce Russel. 2013. Human Resources Management: An Experimental Approach. International Edition. Singapore: McGraw-Hill.

Calquit, Leson A., Lepine Jeffrey A., \& Michael J. Wesson. 2012. Organizational Behavior. New York: McGrawHill.

Crystal, David. 2003. English As a Global Language. Cambridge: Cambridge University Press.

Cushway, Barry. 2002. Human Resources Managemnt. Singapore: Cogan Page.

D’Aprix, Roger. 1982. Communication for Productivity. New York: Harper \& Row Devito.

Davis, Keith \& John, W. Newstrom. 2006. Organizational Behavior: Reading and Exercises. Michigan: McGrawHill.

Dessler, Gary. 2013. Human Resources Management. Thirteenth Edition. USA: Pearson Global Edition.

Gragne, Marylene \& Jacques Forest. 2011. The Study of Compensation Systems Through The Lens of SelfDetermination Theory.

Gibson, James, John Ivancevich, James H. Donelly \& Robert Koopaske. 2008. Organizational Behavior, Structure and Process. McGraw-Hill/Irwin. 
Hampton, R. David, Summer, Edgar Charles \& Ross A. Webber. 2008. Organizational Behavior and The Practice of Managements. $4^{\text {th }}$ Edition. Boston: McGraw-Hill

Hasibuan, Melayu S.P. (2007). Dasar-dasar Perbankan (Principles of Banking). Jakarta: PT. Bumi Aksara.

Herzberg, Frederick. 1968. The Hygiene Motivation Theory. London: Chartered Management Institute

Kalla, H. K. 2006. Integrated Internal Communication: A. Multidisciplinary Perspective Corporate Communication. Helsinki School of Economics.

Kreitner, Robert, \& Angelo Kinicki. 2000. Perilaku Organisasi. Indonesian Edition. Jakarta: Salemba Empat Publisher.

Kumar, N., \& R. C. Rosse. 2010. Examining The Link Between Islamic Work Ethic and Innovation Capability. Journal of Management Development 29 (1) p. 79-93.

Lussier, Robert N., \& Achua Christopher F. 2010. Leadership: Theory, Application, and Skill Development. Changage Learning.

Luthans, Feared. 2008. “Corporate Culture: Challenge to Excellence. Indonesian Edition. Jakarta: PT. Elexmedia Komputindo.

Luthans, Sweeny \& Mc. Farli. 2008. Organizational Behavior. Singapore: McGraw-Hill.

Malthis, Robert L., \& John H. Jackson. 2002. Manajemen Sumber Daya Manusia. Indonesian Edition. Jakarta: Salemba Empat Publisher.

McClelland, David C. 1978. Managing Motivation to Expand Human Freedom. American Psychologist. 33(3) 201-210.

Ming, Chun Tsai, Chan Chung Ching \& Chang Ya-Yuan. 2010. Drivers of Hospital Industry Employees' Job Satisfaction, Organizational Commitment and Job Performance. African Journal of Business Management, Vol. 4 (18), 4118-4138, Dec.

Mondy, R. Wayne \& Robert M. Noe. 2006. Human Resources Management. Pearson/Prentice Hall

Mubarok, Endang Saefuddin \& Juwiko Darmawan. 2019. The Influence of Training, Motivation, and Work Ethics on the Internal Communication and Their Impact on The Employee Performance. European Journal of Business and Management Vol. 11, No. 24.

Mubarok, Endang Saefuddin. 2019. The Effect of Organizational Culture and Work Motivation on Employee Performance: The Mediating Role of Job Satisfaction. European Journal of Business and Management Vol. 11 , No. 35

Neatle, M.A. \& G.B. Noetheraft. 1991. Behavioral Negotiation Theory. Research in Organizational Behavior. 13: p. $147-190$

Pace, R. Wayne \& Don F. Faules. 2000. Komunikasi Organisasi: Strategi Meningkatkan Kinerja Perusahaan. Indonesian Edition. Bandung: PT. Remaja Rosdakarya.

Pettit, JD., Jose R. Goris dan B. B. Vaught. 2007. An Examination of Organizational Communication of Organization as a Moderator of The Relationship Between Job Performance and Job Satisfaction.

Reggio, E. Ronald, Susan E. Murphy \& Firozzolo J. Francis. 2008. Multiple Intellegences and Leadership. Colombia, Lawrence Erlbaum Associates.

Robbins, Stephen P. 2003. Perilaku Organisasi. Indonesian Edition. Jakarta: PT. Index Jakarta Publisher.

Robbinson, P. Stephen \& Timothy A. Judge. 2011. Organizational Behavior. New Jersey: Prentise Hill.

Rogusa, Antonio. 2010. Internal Communication Management: Individual and Organization Outcomes. Antonio Rogusa \& Ventas Publishing ApS ISBN 978-87-7681-602-605.

Rucky, Ahmad S. 2009. Sistem Manajemen Kinerja. Jakarta: PT. Gramedia Pustaka Utama.

Sohail, Amir, Safdar, Robina, Saleem, Salma., Ansar, Samara., \& Azeem, M. 2014. Effect of Work Motivation and Organizational Commitment on Job Satisfaction. Global Journal of Management and Business Research: Administration and Management. Vol. 14 No. 6

Sriwidodo, Untung, and Budi Agus Haryanto. 2010. Pengaruh Kompetensi, Motivasi, Komunikasi dan Kesejahteraan Terhadap Kinerja Pegawai Dinas Pendidikan Kabupaten Sukoharjo. Jurnal Manajemen Sumber Daya Manusia Vol. 4 No. 1, June 2010.

Subari. 2014. Pengaruh Pelatihan, Kompetensi dan Motivasi Terhadap Kinerja Karyawan, Dimoderasi Oleh Komunikasi Internal. Jakarta.

Sutawa, Gusti Kade. 2015. Human Resources Empowerment, Working Motivation, and Organization Change in Improving the Performance of Hotel Business in Bali. Denpasar: Udayana University.

Vinzi, V. Eposito., W. W. Chin, J. Henseler \& H. Wang. 2010. Handbook of Partial Least Squares: Concepts, Methods, and Applications. New York: Spinger.

Wexley, K. W. \& Gray A. Yulki. 2010. Organizational Behavior and Personal Psychology. Homewood Illionis, Richard D. Irwin

Oshagbemi, T. (1997), "Job satisfaction and dissatisfaction in higher education”, Education + Training, 39 (9), 354-359 